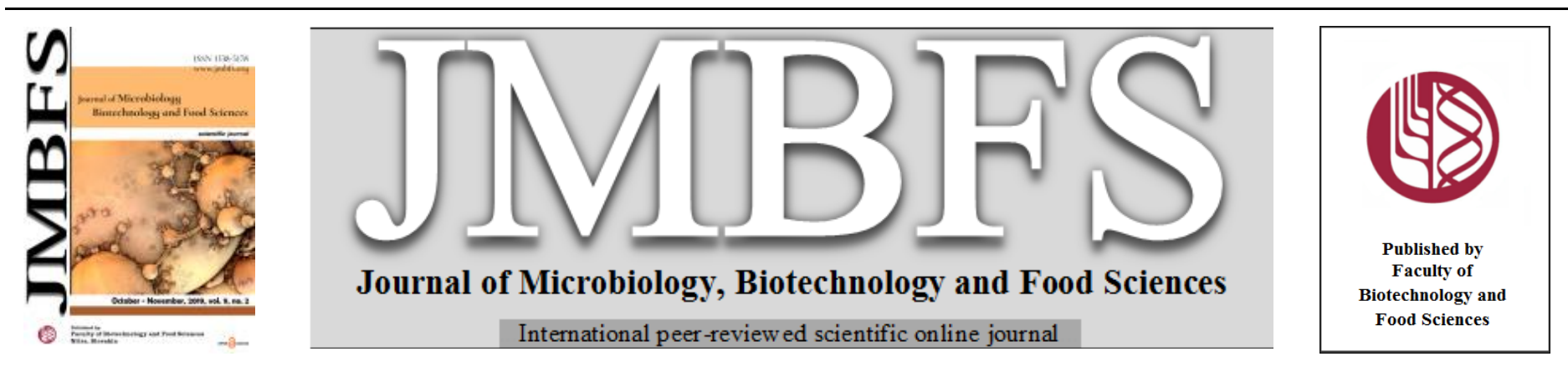

\title{
INFLUENCE OF CARBON SOURCE ON EXTRACELLULAR PROTEASE PRODUCTION BY SOIL STREPTOMYCES SP. AGS-10
}

\author{
Daniela G. Hurtado-Cantillol ${ }^{1}$,Angélica Moreno-Enríquez², Zahaed Evangelista-Martínez ${ }^{1 *}$
}

$\operatorname{Address(es):~}$

${ }^{1}$ The Center for Research and Assistance in Technology and Design of the State of Jalisco, AC (CIATEJ), Southeast Unit, Tablaje Catastral $31264 \mathrm{~km} 5.5$ Carretera. Sierra Papacal - Chuburná Puerto. Scientific Technology Park of Yucatán. CP 97302. Mérida, Yucatán, México.

${ }^{2}$ The Marist University of Merida, Periférico Norte Tablaje Catastral 13941 Carretera Mérida-Progreso. C.P. 97300. Mérida, Yucatán, México.

*Corresponding author: zevangelista@ ciatej.mx

doi: 10.15414/jmbfs.2019.9.2.236-241

ARTICLE INFO

Received 7. 7. 2018

Revised 4. 4. 2019

Accepted 9. 4. 2019

Published 1. 10. 2019

Regular article open $\partial_{\text {ACCESS }}$

\begin{abstract}
The aim of this study was to screen and select streptomycetes exhibiting the production of extracellular proteases and evaluates the effect of carbon sources on protease expression. An acidic precipitation of non-degraded casein was performed to monitor the hydrolytic activity of protease-producing isolates on proteolysis medium (PM). Furthermore, we assessed the induction/repression status of protease production depending on the carbon sources. Clear halos surrounded the colonies were measured to calculate the Enzymatic Index (EI) values. One-hundred and sixty-eight streptomycete strains were screened in order to identify protease producers. Among all of these, the Streptomyces sp strain AGS-10 was selected based on their highest EI value. When sucrose, xylose, and arabinose were added to PM as carbon source, the EI were not modified. Conversely, the presence of lactose, glucose, and fructose repressed the proteolytic activity displayed by the AGS-10 colonies. A supernatant obtained from a culture media seeded with AGS-10 also displayed an extracellular proteolytic activity that was detected by an agar well diffusion assay. However, when lactose or glucose was added to the culture media the resulting proteolytic activity from supernatant was lost. The study shows a negative influence of some carbon sources for protease production.
\end{abstract}

Keywords: protease, streptomycetes, carbon repression, casein precipitation

\section{INTRODUCTION}

The use of enzymes for industrial catalytic purposes has significantly increased during the last decades, estimating that the global market for these enzymes reached $\$ 3.3$ billion USD in 2010, $\$ 4.4$ billion in 2015 and it is estimated that by 2022 it will reach $\$ 6.30$ billion (Binod et al., 2013; Markets and Markets, 2018). Because of their wide applications range in the food, beverage, detergent, and biofuel industries, proteases constitute the most important market share of the industrial enzyme production, accounting for $60 \%$ of sales worldwide (Kirk $\boldsymbol{e} t$ al., 2002; Sandhya et al., 2005).

The species from the genus Streptomyces are the most widely used in this industry and comprise a diverse group of Gram-positive bacteria belonging to the phylum Actinobacteria. Distinctively, they undergo a complex process of morphological differentiation in which branched mycelium develops into aerial mycelia, sporophores and spores (Anderson and Wellington, 2001). They produce a broad spectrum of highly valued bioactive compounds for commercial purposes. Some of them are of medical interest, especially those displaying antifungal, antiviral, antitumor, anti-hypertensive, immunosuppressant, and antibiotic activities (Takizawa et al., 1993; Berdy, 2005; Procópio et al., 2012). Similarly, hydrolytic enzymes are of great importance for various industrial purposes, as they are used in the manufacture of food, drugs and agricultural inputs, such as celluloses, chitinases, amylases, xylanases, proteases, lipases and esterases (Sathya and Ushadevi, 2014; Vaijayanthi et al., 2016).

Some Streptomyces species produce different proteolytic enzymes according to the substrate in which they live, as well as their inherent capacity to degrade the organic matter contained in soil. However, a critical benefit of many proteolytic enzymes produced by streptomycetes is their secretion into extracellular compartments. This feature is generally regarded as safe (GRAS) by the U.S Food and Drug Administration (Ghorbel et al., 2014). Moreover, this represents an advantage for purification purposes, since mycelia may be easily separated from the enzyme solution by simple filtration or centrifugation before the process of purification of enzyme in order to achieve homogeneity.

Several protease-producing Streptomyces spp. from a wide spectrum of substrate have been previously described. In this regard, S. thermovulgaris produced more than one type of serine- and metallo- proteases when grown on rapemeal-derived media (Yeoman and Edwards, 1994). An alkaline protease used to remove blood stains from surgical instruments was produced by $S$. gulbangersis using wheat bran in a solid-state fermentation process (Vishalakshi et al., 2009). A partial characterization of the extracellular proteases produced by $S$. clavuligerus was carried out and the enzyme was produced through a batch fermentation process using a soy bean filtrate (Moreira $\boldsymbol{e t}$ al., 2001). Recently, an alkaline protease produced by $S$. griseorubens was used to control root rot disease caused by Rhizoctonia in corn (Al-Askar $\boldsymbol{e t}$ al., 2015). The aim of this study is to screen and select streptomycetes exhibiting proteolytic activity and evaluate the effects of carbon sources on protease expression. Additionally, this study will show the characterization and molecular identification of the AGS-10 protease-producing isolate.

\section{MATERIAL AND METHODS}

\section{Culture media and growth conditions}

ISP 2 (International Streptomyces Project) agar media was used to grow cells and to induce spore production, while ISP 9 agar medium was used during the processes of protein detection and biochemical characterization (Shirling and Gottlieb, 1966). Proteolysis Medium (PM) was prepared by adding 1\% casein from bovine milk (Sigma-Aldrich ${ }^{\circledR}$ C 7078) to the ISP 9 medium (HIMEDIA $®$ ). Strains were maintained at $29^{\circ} \mathrm{C}$ for 14 days.

\section{Screening streptomycetes displaying protease activity}

A screening exercise was carried out in order to detect streptomycetes species producing extracellular proteases. One-hundred and sixty-eight strains preserved in the Germplasm Bank of Actinomycetes of the Center for Research and Assistance in Technology and Design of the State of Jalisco (CIATEJ), Southeast Unit, were used in the study. This collection preserves streptomycetes species from soil samples obtained from mesophyll mountain forests, wetland Ramsar's 
forests, caves and agricultural field's environments (Caraveo et al., 2014; Evangelista-Martínez, 2014ab; Córdova-Dávalos et al., 2018).

A $2-\mu \mathrm{L}$ aliquot from a general inoculum (GI) of spores or cells, previously prepared (Evangelista-Martínez, 2014b), was placed in plates containing PM medium and incubated for 7 days at $29^{\circ} \mathrm{C}$. Proteolytic colonies were detected by adding $5 \mathrm{ml}$ of a $10 \%$ acetic acid solution to Petri plates for five minutes at room temperature. The remaining solution was poured-off from the plates and the clear zones surrounding the colonies were measured with Vernier caliper. Clear halos evidenced protease activity. The Enzymatic Index (EI) was assessed by calculating the hydrolyzed zone diameter/colony diameter ratio (Florencio et al., 2012). The strain with the highest EI value was selected for further studies.

\section{Effect of sources of carbon on protease expression}

The effect of different types of sugars on protease expression was evaluated by respectively adding $1 \%$ glucose, fructose, lactose, sucrose, xylose or arabinose to the PM medium containing 1\% casein (Caraveo et al., 2014). As indicated above, a $2 \mu \mathrm{L}$-aliquot of a suspension containing the AGS-10 GI isolate was seeded and kept at $29^{\circ} \mathrm{C}$ for 14 days. EI values were determined using the ratios of the diameter of hydrolyzed zone and that of the colony.

\section{Effect of casein concentration on proteolytic activity}

The effect of casein concentration on proteolytic activity as indicated by the enzymatic index was studied for the selected AGS-10 streptomycete strain. PM plates were supplemented by three levels of casein namely $0.25,0.5$, and $1 \%$. EI was calculated using the ratios of the diameter of hydrolyzed zone and that of the colony.

Proteolytic activity on a cell-free supernatant obtained from the Streptomyces sp AGS-10

Proteolytic extracts were obtained from AGS-10 strain culture grown on 1000 $\mathrm{mL}$ of ISP9 medium supplemented with $1 \%$ casein and $50 \mathrm{ppm}$ antifoam A (Sigma-Aldrich $\AA$ ). The culture was kept at $29^{\circ} \mathrm{C}$ and $150 \mathrm{rpm}$ for $96 \mathrm{~h}$ Supernatant obtained by spinning down cells at $4000 \mathrm{~g}$ for 10 minutes was filtered twice with Whatman paper filter No. 1, and passed through a $0.45 \mu \mathrm{m}$ sterile filter (Millex ${ }^{\circledR G V}$, Merck-Millipore). The cell-free extract was dialyzed three times by using $50 \mathrm{mM}$ sodium acetate buffer, $\mathrm{pH} 7.6$ and $20 \%$ glycerol. It was subsequently stored at $-20^{\circ} \mathrm{C}$ until further use. Protein concentration was determined using the Bradford assay.

The supernatant proteolytic activity was evaluated through the agar well diffusion assay. A $50 \mu \mathrm{L}$ supernatant aliquot containing 15-100 $\mu \mathrm{g}$ protein was placed on the respective wells of a $6 \mathrm{~mm}$-diameter multi-well plate containing $0.5 \%$ of casein dissolved in $1.2 \%$ agar. After a $24-\mathrm{h}$ incubation at $37^{\circ} \mathrm{C}, 10 \mathrm{~mL}$ of $10 \%$ acetic acid were added. The diameter of the clear zones surrounding the wells was measured by using a caliper. For assay validation purposes, $60 \mu \mathrm{g}$ of a commercial protease preparation obtained from Streptomyces griseus (SigmaAldrich ${ }^{\circledR}$ P5147) dissolved in $100 \mathrm{mM}$ Tris-HCl buffer $\mathrm{pH} 7.2$ was used.

\section{Characterization of the AGS-10 isolate}

The morphological and biochemical characterization of the isolate was carried out (Shirling and Gottlieb, 1966). The effects on substrate mycelium, spore mass, and pigment production were evaluated under the following conditions: carbon source assimilation, different agar culture media, growth at several $\mathrm{pH}$ values (4-9), and different sodium chloride concentrations (2.5-15\%). All tests were performed in 24-wells cell culture plates

Antibiotic susceptibility assays were carried out by using Gram positive II

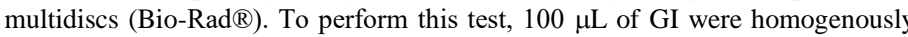
dispersed in ISP 2 agar media. Subsequently, a multidisc was placed on the plate. Either resistance or susceptibility was evaluated after a 14-day incubation at $29^{\circ} \mathrm{C}$, according to the manufacturer's instructions.

\section{Molecular Identification}

The identity of the selected strain was determined based on partial length $16 \mathrm{~S}$ rRNA gene sequence analysis. The genomic DNA used as template for PCR was prepared according to the procedure described by Evangelista-Martínez (2014b). The complete $16 \mathrm{~S}$ rRNA gene fragment was prepared by PCR

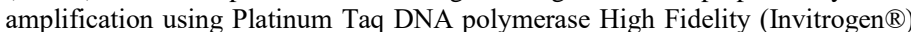
and oligonucleotides 63F (5'-CAGGCCTAACACATGCAAGTC-3') and 1389R (5'-ACGGGCGGTGTGTACAAG-3') (Osborn et al., 2002). The PCR reaction was carried out in a total volume of $50 \mu \mathrm{l}$ that contained $1 \mathrm{X}$ PCR buffer, $2 \mathrm{mM} \mathrm{MgSO} 4,0.2 \mathrm{mM}$ of each dNTP, $2 \mathrm{ng}$ of chromosomal DNA, $0.4 \mu \mathrm{M}$ each primer and 2 units of Taq DNA polymerase. PCR conditions were: an initial denaturation step at $94^{\circ} \mathrm{C}$ for 5 min followed by 35 amplification cycles of $94^{\circ} \mathrm{C}$ for 1 minute, $55^{\circ} \mathrm{C}$ for 45 seconds, and $68^{\circ} \mathrm{C}$ for 1 minute. The amplified fragment was purified using the PureLink PCR Purification Kit (Invitrogen $($ ) and was verified directly by nucleotide sequence determination of both strands
Sequencing was provided by LANGEBIO (National Laboratory of Genomics for Biodiversity, CINVESTAV Irapuato, Mexico). Sequences were assembled and trimmed using CLC Main Workbench 5.6 (Qiagen ${ }^{\circledR}$ ). A 1236 bp DNA fragment was analyzed for homology using the BLASTN program and 16S rDNA gene sequences of typed strains of various genera were retrieved from the nonredundant GeneBank database (http:// blast.ncbi.nlm.nih.gov/) (Alschul et al. 1997). These sequences, in conjunction with additional streptomycete strains were used as reference in which unidentified and unpublished sequences were not included. Phylogenetic analysis was carried out at Phylogeny.fr web page: http://www.phylogeny.fr/phylogeny.cgi (Dereeper et al., 2008; Dereeper et al. 2010). Selected sequences were aligned with CLUSTAL W (v 2.1) configured for highest accuracy. After alignment, positions with gaps were removed from the alignment. The phylogenetic tree was reconstructed using the neighbor joining method implemented in the BioNJ program. The Jukes-Cantor substitution model was selected for the analysis. The confidence of the grouping was verified by bootstrap analysis (500 replications). Graphical representation and editing of the phylogenetic tree were performed with TreeDyn ( $\mathrm{v}$ 198.3) Bacillus subtilis subsp. subtilis was used as outgroup. Partial sequence of $16 \mathrm{~S}$ rDNA gene of Streptomyces sp. isolate AGS-10 was deposited in GenBank database under accession number MF135615.

\section{Statistical Analysis}

All experiments were done in triplicate and data were analyzed using two-way analysis of variance (ANOVA) at $\mathrm{P}=0.05$ with Statgraphics ${ }^{\circledR}$ Centurion XVI software version 10

\section{RESULTS AND DISCUSSION}

\section{Selection and characterization of protease-producing Streptomyces}

An initial screening to detect proteases was essential in order to select previously unidentified producer strains (Kasana et al., 2011). One-hundred and sixty-eight streptomycetes isolates were initially screened in order to detect their proteolytic activity. Sixty-three of them exhibited clear 7-21 mm-diameter hydrolytic halos surrounding the colonies. These helped to discriminate precipitated casein from its non-hydrolyzed formed (Figure 1). The highest EI rate values $(2.63 \pm \mathrm{SD}$ $0.06,2.42 \pm \mathrm{SD} 0.2,2.15 \pm \mathrm{SD} 0.06$ ) were observed for three isolates (named AGS-10, AGS-17 and AGS-21, respectively). Because the AGS-10 isolate showed the highest EI value and superior cultural characteristics and profuse spore production, it was selected for further experiments.

The incorporation of skimmed milk, gelatin, egg-yolk or casein in solid agar media formulations have been used to perform microbial protease screening. Some of these methods have used developing agents intended to elicit the hydrolytic activity, e.g. trichloroacetic (TCA) or tannic acids (Medina and Baresi, 2007; Saran et al., 2007; Suganthi et al., 2013). In the present study, precipitation of casein with acetic acid correlate with the white zone of nonhydrolysed protein. In contrast, translucent zone around the colonies correlated with the hydrolytic activity of extracellular proteases.

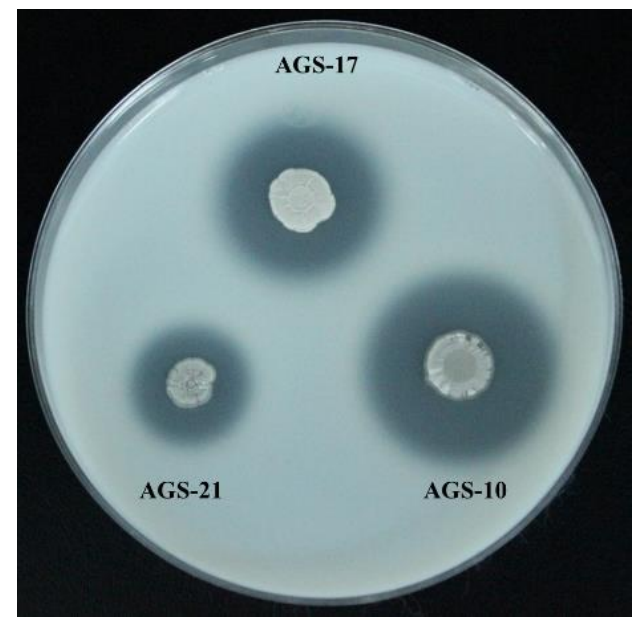

Figure 1 Screening of proteolytic streptomycetes. Isolates exhibit clear halos zone of different diameters around the colonies correlated with the hydrolysis of casein

\section{Effect of carbon source on protease expression}

It has been previously described that extracellular enzyme production is greatly influenced by ingredients on the media, especially carbon and nitrogen sources (Caraveo et al., 2014). The effect of glucose, fructose, lactose, sucrose, xylose, and arabinose on the extracellular protease production carried out by the AGS-10 
isolate is shown in Figure 2. The obtained results revealed that sucrose, xylose and arabinose did not modify protease expression as protease activity was similar to that using casein alone (EI values $=2.8,2.6,2.8$, and 2.9, respectively) (Figure 2a). However, it has been also observed that lactose, glucose or fructose addition produced a decreased proteolysis halo, and this may correlate with a catabolite repression effect as shown in Figure 2b. Moreover, EI values decreased from 4.1 to 2.9 after increasing the proteolytic substrate levels (Figure $2 \mathbf{c}$; statistically significant differences, $\mathrm{p}=0.05$ ). This suggests that substrate concentration impacts on enzyme reaction rate or, if the product is in excess, protease expression is turned-off or repressed. Previous studies indicated that glucose was the optimal carbon source to induce extracellular protease production by Streptomyces carpaticus (Haritha et al., 2012). Streptomyces sp. DPUA1576, a suitable microorganism that produces proteases and fibrinolytic proteins, displayed a maximum protease production when grown on a medium consisting of soybean flour $1.26 \%$ and glucose $1.23 \%$ (Silva et al., 2015). Similarly, a high protease yield was detected when $S$. albolongus was grown in a medium containing $1 \%$ glucose, $2 \%$ beef extract, and $0.2 \%$ yeast extract as carbon and nitrogen source (Akhtar et al., 2013). Protease production by S. griseus increases when Triton X-100 and SDS were included in the basal medium (El-Shahed $\boldsymbol{e t}$ al., 2008).

\section{Proteolytic activity in supernatants obtained from culture media}

The protease activity of supernatants obtained from cell cultures was evaluated on agar plates containing PM (Figure 3). Increasing supernatant amounts obtained from the AGS-10 strain were placed on well plates containing PM and the clear zones resulting from hydrolysis were measured. The hydrolytic activity was plainly visible and increased linearly with enzyme concentration (Figure 3a). As mentioned on the methods section, two supernatants used as control (40 $\mu \mathrm{g}$ ) did not produce a clear hydrolysis zone because protease expression was decreased by the presence of glucose and lactose, as previously discussed (data not shown). A comparative assay performed by the well diffusion agar method confirmed that the proteolytic activity of the AGS-10 protease supernatants and a commercial protease obtained from Streptomyces griseus directly correlated with the clear area (Figure 3b). Additionally, these results confirmed that precipitation of casein micelles in acidic conditions may be useful to screen proteaseproducing microorganism in a straightforward manner. For instance, Figure 4 showed a more conclusive hydrolytic halo (well-defined), resulting from the acidic precipitation assay when compared to an assay intended to detect extracellular protease activity using a Coomassie Blue staining (Vermelho et al., 1996).

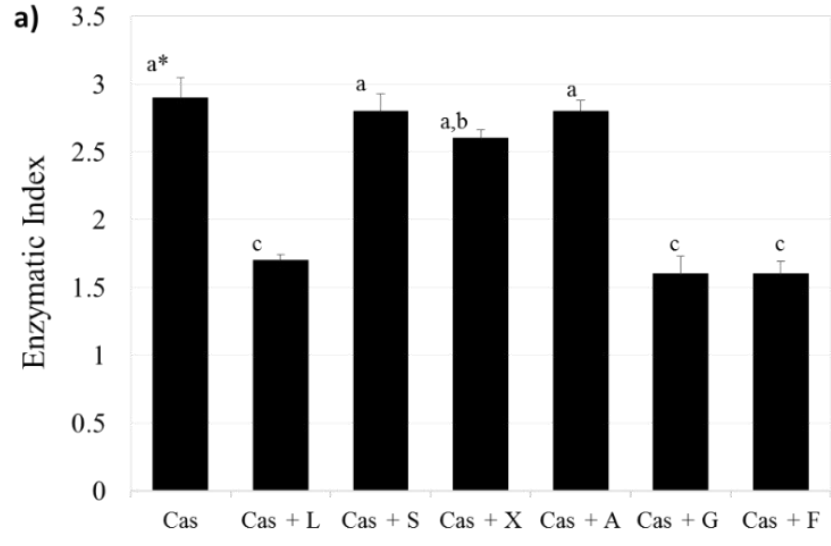

b)

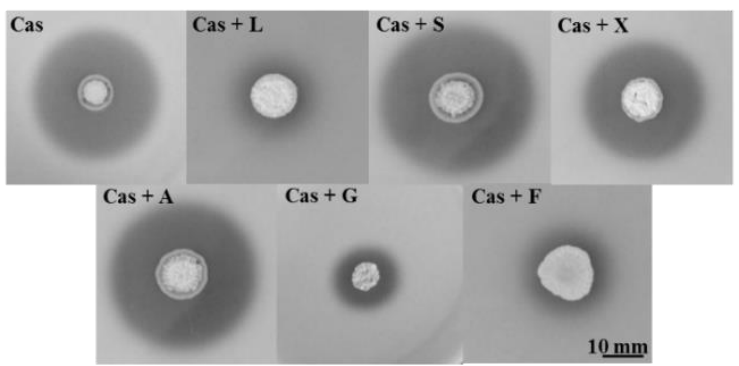

c)

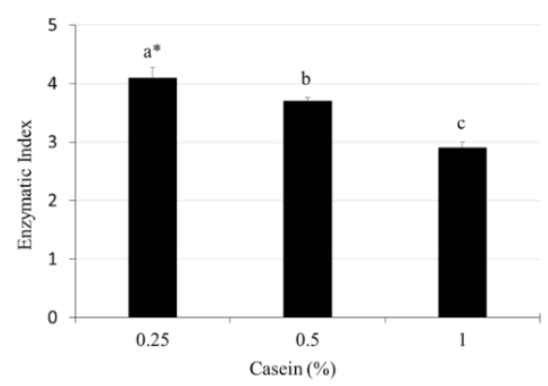

Figure 2 Effect of carbon source on protease expression from Streptomyces $\mathrm{sp}$ AGS-10. a) Enzymatic Index obtained from 7 days old cultures. b) Visualized effect of carbon source over the protease production. c) Enzymatic Index of Streptomyces sp AGS-10. Spores were inoculated on PM agar plates with 0.25 , 0.5 and $1 \%$ of casein and incubated at $29^{\circ} \mathrm{C}$, hydrolysis halos were measured after 7 days. * The bars that show the same letters are not significantly different $(\mathrm{P}=0.05)$

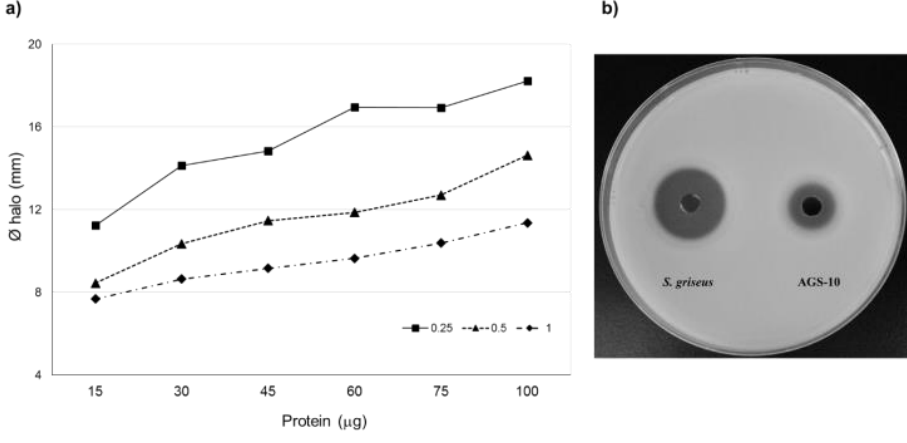

Figure 3 Proteolytic activity of Streptomyces sp AGS-10. a) Increased concentrations of the enzymatic extract supernatant were deposited into $6 \mathrm{~mm}$ wells on Petri plates with three casein concentrations and measured after 24 hours of incubation at $29^{\circ} \mathrm{C}$. b) Proteolytic activities of enzymes from Streptomyces griseus and concentrated supernatant from Streptomyces sp AGS-10. Left halo, $10 \mu \mathrm{g}$ of $S$. griseus protease (diameter: $22.0 \mathrm{~mm} \pm 1.3 \mathrm{SD}$ ); right halo, $40 \mu \mathrm{g}$ of the concentrated supernatant from AGS-10 (diameter: 16.2 $\pm 1.8 \mathrm{SD}$ ) 


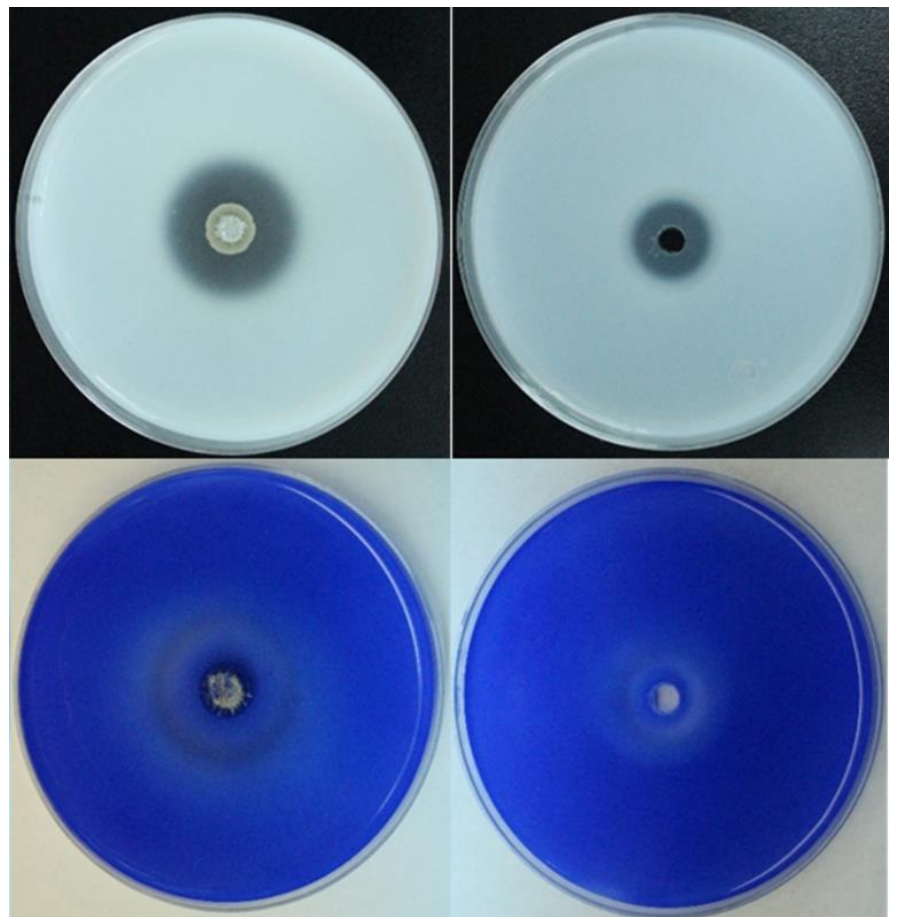

Figure 4 Comparative methods to detect extracellular protease activity from colonies (left column) and enzyme extract (right column) of Streptomyces sp AGS-10 on PM plates with $1 \%$ casein. Upper panel, plates flooded with acetic acid; botton panel, plates flooded with Coomassie blue stain.

Mokashe and Patil (2016) described an alternative method to quantify the enzymatic activity of purified proteases using a substrate-agarose plate diffusion method. Their bioassay avoids the use of a detection reagent (e.g. Coomassie blue dye or Trichloroacetic acid), and quantifies the enzyme units in a simple way. It could be interesting to evaluate the protease expression of Streptomyces sp AGS-10 under these conditions.

\section{Phenotypic characterization and molecular identification of the AGS-10} isolate

The morphological features displayed by the selected isolate were observed for 21 days. The strain was characterized by an extensively branched mycelium that developed into an aerial mycelium with a flocculate appearance and a mass of mature spores possessing grey to black coloration. The details of this characterization are shown in Table 1. It shows a suppressive effect on sporulation mediated by some types of sugars. Raffinose, fructose and sucrose suppressed growth and spore production. The adaptability of AGS-10 isolate to different substrates was evidenced by its growth in the presence of different carbon and nitrogen sources. Vegetative growth and sporulation were noticeable when cells were cultured on the following media: International Streptomyces Project 2 and 3, nutrient agar, potato-dextrose agar, and tryptone-yeast extract agar. The observed physiological features showed that the isolate under study develops an extensive substrate mycelium producing a massive spore mass at $\mathrm{pH}$ values ranging from 6 to 9. Optimal growth and a moderate spore mass were observed up to $7.5 \%$ sodium chloride. The antibiotic susceptibility profile showed that the isolate was resistant to gentamicin and levofloxacin, as shown on (Table 2).

Table 1 Characterization of Streptomyces sp. AGS-10

\begin{tabular}{lllll} 
Test & & Carbon source & Growth* & Spore \\
Gram staining & + & None & ++ & ++ \\
Starch hydrolysis & + & D-glucose & +++ & +++ \\
Casein hydrolysis & + & Sucrose & + & - \\
Melanin production & - & D-xylose & +++ & ++ \\
& & D-mannose & +++ & +++ \\
Growth on ISP2 & & D-arabinose & + & - \\
Substrate mycelium & Yellow & D-raffinose & + & + \\
Aerial mycelium & White & D-cellobiose & ++ & +++ \\
Spore mass & Black & D-fructose & + & + \\
Pigment production & None & L-rhamnose & +++ & ++ \\
& & Galactose & ++ & ++ \\
& & Myo-inositol & ++ & - \\
\hline The classification of growth and spore production & was: $(+++)$, excellent; $(++)$
\end{tabular}

* The classification of growth and spore production was: $(+++)$, excellent; $(++)$, moderate; $(+)$, poor; $(-)$, not detected
Table 2 Biochemical and physiological properties of Streptomyces sp AGS-10

\begin{tabular}{|c|c|c|c|c|}
\hline $\begin{array}{l}\text { Culture } \\
\text { media }\end{array}$ & Growth ${ }^{*}$ & Spore & Antibiotic $^{\dagger}$ & Sensitivity \\
\hline ISP9 & ++ & ++ & Ampicillin $10 \mathrm{mg}$ & $\mathrm{R}$ \\
\hline ISP2 & +++ & +++ & Cefalotin $30 \mathrm{mg}$ & $\mathrm{R}$ \\
\hline MH & ++ & + & Cefotaxime $30 \mathrm{mg}$ & $\mathrm{R}$ \\
\hline NA & +++ & +++ & Levofloxacin $5 \mathrm{mg}$ & $\mathrm{S}$ \\
\hline PDA & +++ & +++ & Cefuroxime $30 \mathrm{mg}$ & $\mathrm{R}$ \\
\hline TSI & + & - & Dicloxacillin $1 \mathrm{mg}$ & $\mathrm{R}$ \\
\hline LB & ++ & + & Erythromycine $15 \mathrm{mg}$ & $\mathrm{R}$ \\
\hline TYE & ++ & ++ & Gentamicin $10 \mathrm{mg}$ & $\mathrm{S}$ \\
\hline LIA & +++ & ++ & Cefepime $30 \mathrm{mg}$ & $\mathrm{R}$ \\
\hline SDA & +++ & + & Penicillin $10 \mathrm{U}$ & $\mathrm{R}$ \\
\hline SCA & + & + & Tetracycline $30 \mathrm{mg}$ & $\mathrm{R}$ \\
\hline ISP3 & +++ & +++ & $\mathrm{Tp}-\mathrm{Sm}^{\S} 25 \mathrm{mg}$ & $\mathrm{R}$ \\
\hline \multicolumn{5}{|l|}{ pH } \\
\hline 6 to 9 & +++ & +++ & & \\
\hline \multicolumn{5}{|l|}{$\mathrm{NaCl}(\%)$} \\
\hline $0-2.5$ & +++ & +++ & & \\
\hline $5.0-7.5$ & +++ & ++ & & \\
\hline
\end{tabular}

* The classification of growth and spore production was: (+++), excellent; $(++)$, moderate; (+), poor; (-), not detected.

$\dagger$ Results regarding antimicrobial susceptibility were: (R), resistant; (I), intermediate; (S), susceptible.

${ }^{\S} \mathrm{Tp}-\mathrm{Sm}=$ Trimethoprim-sulfamethoxazole

\section{Phylogeny of Streptomyces sp. AGS-10}

A fragment of the 16S rRNA gene sequence of Streptomyces sp AGS-10 was analysed and it exhibited high similarity $(100 \%)$ to other streptomycete species in the GenBank database (NCBI), especially $S$. mutabilis. A phylogenetic tree was constructed based on the neighbor-joining method and it showed that this strain is allocated to a defined branch along with $S$. mutabilis, S. albogriseolus, S. goshikiensis, $S$. radiopugnans, and $S$. finlayi (Figure 5). This cluster includes species previously studied as biocontrol agents for fungal plant pathogens (Faheem et al., 2015; Luo et al., 2015), for nematicidal production (Zeng et al. 2013), and for resistance to ${ }^{60} \mathrm{Co}$ gamma (Mao et al., 2007).

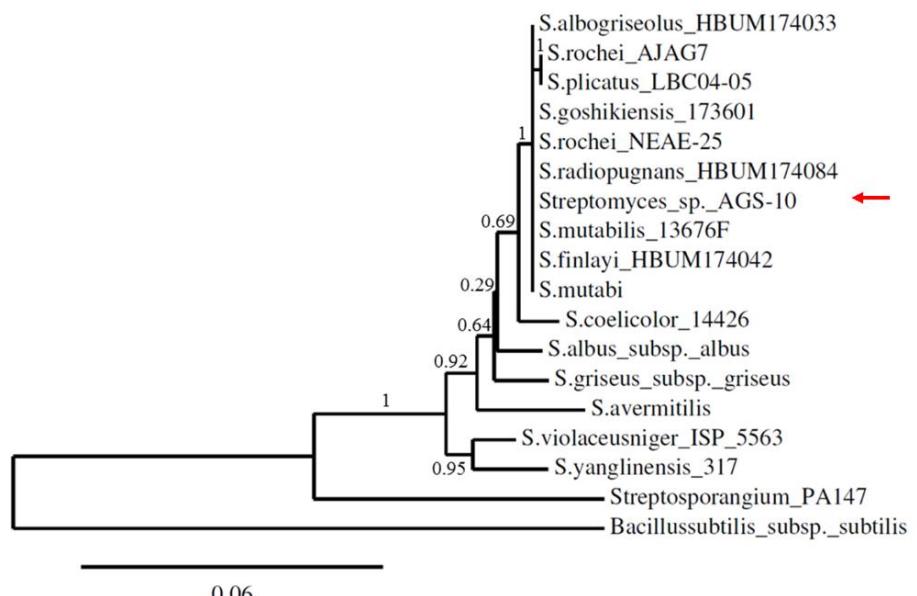

Figure 5 Phylogenetic tree based on $16 \mathrm{~S}$ rDNA sequences showing the relationship between Streptomyces sp. AGS-10 and related species of the genus The numbers at the nodes indicate the levels of bootstrap support based on neighbor-joining analyses of 500 resampled data sets.

\section{CONCLUSION}

Novel proteases displaying different catalytic activities are highly required by some industrial sectors, particularly those producing detergents, leather-derived products, medical devices, processed foods, feeds, and chemicals. In this regard, some Streptomyces species should be considered as protease producers because of their ability to secrete many extracellular enzymes, generally regarded as safe (GRAS).

This study revealed a direct correlation between protease production and carbon sources. An induced or repressed effect on protease production was observed based on hydrolysis halos used to select those proteolytic strains. The detection of hydrolysis halos by using our established procedure is based on the measurement of a clear area. This is a straightforward and efficient way to generate semi-quantitative data. This simple procedure was based on casein's physicochemical property to unfold when exposed to acid conditions, the rearrangement of the long polymer chains and its precipitation. This procedure may be adapted in order to perform a primary or a secondary screening of a large number of strains. 
Acknowledgments: This study was supported in-part by grants CAMP-2008C01-96874 and AGS-2011-C02-181930. To Dr. Alvaro Hernández-Flores and Babatunde O. Musa for English corrections.

\section{REFERENCES}

AKHTAR, N., MAHMUD, A.S.M., KHAN, M.S., TAZNIN, T., HAQUE, M.E., SULTANA, S. 2013. Effects of cultural conditions on the production of extracellular protease by Streptomyces albolongus and Streptomyces aburaviensis. Enzyme Engineering, 2, ID 1000110 http://dx.doi.org/10.4172/eeg.1000110

AL-ASKAR, A.A., RASHAD, Y.M., HAFEZ, E.E., ABDULKHAIR, W.M., BAKA, Z.A., GHONEEM, K.M. 2015. Characterization of alkaline protease produced by Streptomyces griseorubens E44G and its possibility for controlling Rhizoctonia root rot disease of corn. Biotechnology and Biotechnological Equipment, 29, 457-462. https://doi.org/10.1080/13102818.2015.1015446 ALSCHUL, S.F., MADDEN, T.L., SCHAUMLFFER, A.A., ZHANG, J., ZHANG, Z., MILLER, W., LIPMAN, D.J. 1997. Gapped BLAST and PSIBLAST: a new generation of protein database search programs. Nucleic Acids Research, 25 ,

3389-3402. https://www.ncbi.nlm.nih.gov/pmc/articles/PMC146917/pdf/253389.pdf ANDERSON, A.S., WELLINGTON, E.M. 2001. The taxonomy of Streptomyces and related genera. International Journal of Systematics and Evolutionary Microbiology, 51, 797-814. https://doi.org/10.1099/00207713-51-3-797

BERDY, J. 2005. Bioactive microbial metabolites. Journal of Antibiotics, 58, 1 26. https://doi.org/10.1038/ja.2005.1

BINOD, P., PALKHIWALA, P., GAIKAIWARI, R., NAMPOOTHIRI, K.M, DUGGAL, A., DEY K., PANDEY, A. 2013. Industrial enzymes: present status and future perspectives for India: present scenario and perspectives. Journal of Scientific and Industrial Research, 72, 271-286. http://nopr.niscair.res.in/handle/123456789/17451

CARAVEO, M.L.J., MEDINA, C.H.M., MONTALVO, R.C., RODRÍGUEZBUENFIL, I.M., EVANGELISTA-MARTÍNEZ, Z. 2014. A simple plate assay for the screening of naringinase producing streptomycetes. Journal of Microbiological Methods, 102, https://doi.org/10.1016/j.mimet.2014.04.003

CORDOVA-DÁVALOS, L.E., ESCOBEDO-CHÁVEZ, K.G., EVANGELISTAMARTÍNEZ, Z. 2018. Inhibition of Candida albicans cell growth and biofilm formation by a bioactive extract produced by soil Streptomyces strain GCAL-25. $\begin{array}{llll}\text { Archives of Biological } & \text { Science, 70, 387-396. }\end{array}$ https://doi.org/10.2298/ABS170908057C

DEREEPER, A., GUIGNON, V., BLANC, G., AUDIC, S., BUFFET, S. CHEVENET, F., DUFAYARD, J.F., GUINDON, S., LEFORT, V., LESCOT, M., CLAVERIE, J.M., GASCUEL, O. 2008. Phylogeny.fr: robust phylogenetic analysis for the non-specialist. Nucleic Acids Research, 1, W465-9. https://doi.org/10.1093/nar/gkn180

DEREEPER, A., AUDIC, S., CLAVERIE, J.M., BLANC, G. 2010. BLAST EXPLORER helps you building datasets for phylogenetic analysis. BMC Evolutionary Biology, 12, 8. https://doi.org/10.1186/1471-2148-10-8

EL-SHAHED, K.Y., EL-DIWANY, A.I., AWAD, H.M. 2008. Enhanced production of streptomycin and hydrolytic enzymes by Streptomyces griseus strains using different types of organic solvents and detergent compounds. Indian $\begin{array}{lllll}\text { Journal of } & \text { Biotechnology, } & 7, & 341-348 .\end{array}$ http://nopr.niscair.res.in/handle/123456789/1848

EVANGELISTA-MARTÍNEZ, Z. 2014a. Isolation of soil actinomycete species from a mesophyll mountain forest and their potential to antagonize fungal pathogens. British Microbiology Research Journal, 4, 272-281. https://doi.org/10.9734/BMRJ/2014/6619

EVANGELISTA-MARTÍNEZ, Z. 2014b. Isolation and characterization of soi Streptomyces species as a potential biological control agent against fungal plan pathogens. World Journal of Microbiology and Biotechnology, 30, 1639-1647. https://doi.org/10.1007/s11274-013-1568-x

FAHEEM, M., RAZA, W., ZHONG, W., NAN, Z., SHEN, Q., XU, Y. 2015. Evaluation of the biocontrol potential of Streptomyces goshikiensis YCXU against Fusarium oxysporum f. sp. niveum. Biological Control, 81, 101-110. http://dx.doi.org/10.1016/j.biocontrol.2014.11.012

FLORENCIO, C., COURI, S., SANCHEZ, F.C. 2012. Correlation between aga plate screening and solid state fermentation for the prediction of cellulase production by Trichoderma strains. Enzymes Research, Article ID 793708 http://dx.doi.org/10.1155/2012/793708

GHORBEL, S., KAMMOUN, M., SOLTANA, H., NASRI, M., HMIDET, N. 2014. Streptomyces flavogriseus HS1: isolation and characterization of extracellular proteases and their compatibility with laundry detergents. Biomed Research International, Article ID 345980 http://dx.doi.org/10.1155/2014/345980

HARITHA, R., SIVAKUMAR, K., SWATHI, A., JAGAN, MOHAN. Y.S.Y.V., RAMANA, T. 2012. Characterization of marine Streptomyces carpaticus and optimization of conditions for production of extracellular protease. Microbiology Journal, 2, 23-35. https://doi.org/10.3923/mj.2012.23.35
KASANA, R.C., SALWAN, R., YADAV, S.K. 2011. Microbial proteases: detection, production, and genetic improvement. Critical Review Microbiology, 37, 262-276. https://doi.org/10.3109/1040841X.2011.577029

KIRK, O., BORCHERT, T.V., FUGLSANG, C.C. 2002. Industrial enzyme applications. Current Opinion of Biotechnology, 13, 345-351. https://doi.org/10.1016/S0958-1669(02)00328-2

LUO, X., WAN, C., ZHANG, L. 2015. Draft Genome Sequence of Streptomyces mutabilis TRM45540, isolated from a hypersaline soil sample. Genome Announcement, 3, e01465-15. https://doi.org/10.1128/genomeA.01465-15

MAO, J., TANG, Q., ZHANG, Z., WANG, W., WEI, D., HUANG, Y., LIU, Z., SHI, Y., GOODFELLOW, M. 2007. Streptomyces radiopugnans sp. nov., a radiation-resistant actinomycete isolated from radiation-polluted soil in China. International Journal of Systematic Evolutionary Microbiology, 57, 2578-2582. https://doi.org/10.1099/ijs.0.65027-0

MARKETS AND MARKETS. 2016. Enzymes Market by Type (Amylases, Cellulases, Proteases, Lipases, and Phytases), Application (Food \& Beverages, Cleaning Agents, and Animal Feed), Source (Microorganism, Plant, and Animal), and Region - Global Forecast to 2022. Report Code: FB 2277. Available from: http://www.marketsandmarkets.com/PressReleases/industrial-enzymes.asp

MEDINA, P., BARESI, L. 2007. Rapid identification of gelatin and casein hydrolysis using TCA. Journal of Microbiological Methods, 69, 391-393. https://doi.org/10.1016/j.mimet.2007.01.005

MOKASHE, N.U., PATIL, U.K. 2016. Quantitative protease assay by substrateagarose plate method. Journal of Microbiology, Biotechnology and Food Science, 6, 791-793. http://doi.org/10.15414/jmbfs.2016.6.2.791-793

MOREIRA, K.A., CAVALCANTI, M.T., DUARTE, H.S., TAMBOURGI, E.B., SILVA, V.L., PORTO, A.L., FILHO, J.L. 2001. Partial characterization of proteases from Streptomyces clavuligerus using an inexpensive medium. Brazilian Journal of Microbiology, 32, 23-28. http://dx.doi.org/10.1590/S151783822001000300010

OSBORN, A.M., MOORE, E.R.B., TIMMIS, K.N. 2000. An evaluation of terminal-restriction fragment length polymorphism (T-RFLP) analysis for the study of microbial community structure and dynamics. Environmental Microbiology, 2, 39-50. https://doi.org/10.1046/j.1462-2920.2000.00081.x

PROCÓPIO, R.E., SILVA, I.R., MARTINS, M.K., AZEVEDO, J.L., ARAÚJO, J.M. 2012. Antibiotics produced by Streptomyces. Brazilian Journal of Infection Disease, 16, 466-471. https://doi.org/10.1016/j.bjid.2012.08.014

SANDHYA, C., MADHAVAN, N.K., PANDEY, A. 2005. Microbial proteases. In: Microbial enzymes and biotransformations. J.L Barredo (ed.), pp. 165-80 The Human Press Inc., New Jersey. USA https://www.springer.com/gp/book/9781588292537

SARAN, S., ISAR, J., SAXENA, R.K. 2007. A modified method for the detection of microbial proteases on agar plates using tannic acid. Journal of Biochemical and Biophysical Methods, 70, 697-699. https://doi.org/10.1016/j.jbbm.2007.03.005

SATHYA, R., USHADEVI, T. 2014. Industrially important enzymes producing Streptomyces species from mangrove sediments. International Journal of Pharmacy and Pharmaceutical Sciences, 6, 233-237. https://innovareacademics.in/journals/index.php/ijpps/article/view/2588/1404 SHIRLING, E.B., GOTTLIEB, D. 1966. Methods for characterization of Streptomyces species. International Journal of Systematic Bacteriology, 16, 313340. https://doi.org/10.1099/00207713-16-3-313

SILVA, G.M.M., BEZERRA, R.P., TEIXEIRA, J.A., PORTO, T.S., LIMAFILHO, J.L., PORTO, A.L.F. 2015. Fibrinolytic protease production by new Streptomyces sp. DPUA 1576 from amazon lichens. Electronic Journal of Biotechnology, 18, 16-19. https://doi.org/10.1016/j.ejbt.2014.11.001

SUGANTHI, C., MAGESWARI, A., KARTHIKEYAN, S., ANBALAGAN, M. SIVAKUMAR, A., GOTHANDAM, K.M. 2013. Screening and optimization of protease production from a halotolerant Bacillus licheniformis isolated from saltern sediments. Journal of Genetic Engineering and Biotechnology, 11, 45-72. https://doi.org/10.1016/j.jgeb.2013.02.002

TAKIZAWA, M., COLWELL, R.R., HELL, R.T. 1993. Isolation and diversity of actinomycetes in the Chesapeake bay. Applied Environmental Microbiology, 59, 997-1002

https://www.ncbi.nlm.nih.gov/pmc/articles/PMC202228/pdf/aem00033-0067.pdf VAIJAYANTHI, G., VIJAYAKUMAR, R., DHANASEKARAN, D. 2016 Actinobacteria: a biofactory of novel enzymes. In: Actinobacteria: Basics and Biotechnological Applications. D. Dhanasekaran (ed). pp. 329-452. InTech, Rijeka Croatia. http://dx.doi.org/10.5772/61436

VERMELHO, A.B., MEIRELLES, M.N.L., LOPES, A., PETINATE, S.D.G. CHAIA, A.A., BRANQUINHA, M.H. 1996. Detection of extracellular proteases from microorganisms on agar plates. Memórias do Instituto Oswaldo Cruz, 91, 755-760. http://dx.doi.org/10.1590/S0074-02761996000600020

VISHALAKSHI, N., LINGAPPA, K., AMENA, S., PRABHAKAR, M., DAYANAND, A. 2009. Production of alkaline protease from Streptomyces gulbargensis and its application in removal of stains. Indian Journal of Biotechnology, 8, 280-285. http://hdl.handle.net/123456789/4741

YEOMAN, K.H., EDWARDS, C. 1994. Protease production by Streptomyces thermovulgaris grown on rapemeal-derived media. Journal of Applied Bacteriology, 77, 264-270. https://doi.org/10.1111/j.1365-2672.1994.tb03073.x 
ZENG, Q., HUANG, H., ZHU, J., FANG, Z., SUN, Q., BAO, S. 2013. A new nematicidal compound produced by Streptomyces albogriseolus HA10002. Antonie van Leeuwenhoek, 103, 1107-1111. https://doi.org/10.1007/s10482-0139890-8 